\title{
Editorial
}

\section{Sustainable Applications in Agriculture}

\author{
Antonio Ruiz-Canales * and Manuel Ferrández-Villena García (1) \\ Department of Engineering, Universidad Miguel Hernandez, 03300 Orihuela, Spain; m.ferrandez@umh.es \\ * Correspondence: acanales@umh.es; Tel.: +34-649581413
}

Citation: Ruiz-Canales, A.; García, M.F.-V. Sustainable Applications in Agriculture. Sustainability 2021, 13, 4136. https://doi.org/10.3390/ su13084136

Received: 2 April 2021

Accepted: 5 April 2021

Published: 8 April 2021

Publisher's Note: MDPI stays neutral with regard to jurisdictional claims in published maps and institutional affiliations.

Copyright: (C) 2021 by the authors. Licensee MDPI, Basel, Switzerland. This article is an open access article distributed under the terms and conditions of the Creative Commons Attribution (CC BY) license (https:/ / creativecommons.org/licenses/by/ $4.0 /)$.
Recently, the European Commission identified the goal to achieve a double transitionecological and digital - as one of the greatest challenges on the areas of the planet across various sectors of the society. In this transition process, the agricultural sector has been incorporating new technologies and methodologies in order to improve the productivity, quality, sustainability, and the efficiency in the use of resources of agricultural production.

Several different aspects regarding sustainability in agriculture can be solved with multidisciplinary technologies.

Firstly, water use efficiency is essential in semiarid regions in order to achieve sustainability. For this purpose, the use of compact removable weighing lysimeters can be a suitable tool for determining the adjusted water amounts that a crop is consuming along the irrigation scheduling. The use of these devices can help farmers to determine the crop water requirements and to improve the irrigation system efficiency. A weighing lysimeter provides a direct method to measure the crop evapotranspiration $\left(\mathrm{ET}_{\mathrm{C}}\right)$ through the mass balance of an isolated soil volume [1,2].

Another consideration related with sustainability in agriculture is the waste management. In general, agriculture is responsible for generating large amounts of waste that are not adequately managed in terms of their environmental treatment and economic administration. Wood residues in the production of wood-based materials have been considered environmentally sustainable, economically viable, and socially acceptable [3], but the deforestation that is taking place in forests prompts us to look for suitable substitutes. Attempts have been made to reduce the use of wood in particle board by introducing mixtures of forest residues [4], whole trees [5], garden tree prunings [6,7], and fruit tree prunings [8]. To meet the demand caused by declining supplies of solid wood and wood-based materials, there has been a marked increase in research using plant fibres in the development of new materials. There are numerous studies where particle boards have been manufactured using vegetable fibres such as cane bagasse [9,10], coconut [11], tea [12], flax and hemp [13], bamboo [14], jute [15], common cane [16,17], and vine prunings [18]. Specifically, the use of wastes of giant reed, which was traditionally used as a construction material in eastern areas of Spain, can be a sustainable application. Adding giant reed particles to wood boards can improve their properties, bringing about considerable industrial and environmental benefits $[19,20]$.

Moreover, agriculture is facing a great number of different challenges due to the increase in demand for food, environmental impacts due to the excessive use of conventional fertilizers, and climate change. This subjects the crops to extreme environmental conditions. One of the solutions to these problems could be the use of biostimulant products that are rich in amino acids (AAs). These substances are substituting and/or complement conventional fertilizers and help plants adapt to climate change [21].

The use of computational tools for optimal natural resources management in agriculture is another way to achieve sustainability. The dispatch of energy and resources in agricultural systems often involves the definition and resolution of optimization problems. The use of multicriteria problems for solving several aspects relating to resources management has been used in several case studies. These aspects are varied, including the relationships between the inputs and outputs of the system and their parametrization, 
among others. Mainly, this is a deterministic mixed-integer linear problem that represents the defined system. This can be applied in agricultural systems (greenhouses, photovoltaic systems, etc.). These tools are including simulations and are being used for decision-making (schedule irrigation and $\mathrm{CO}_{2}$ enrichment, managing storage systems, etc.) [22,23].

The use of remote sensing is another related applied technology for achieving sustainability in agriculture. The evaluation of the agronomic, phenological, nutritional quality, and organoleptic characteristics of crops based on the NDVI (normalized difference vegetation index) can be obtained from satellite imagery. The NDVI is a good index to classify different areas according to productive capacity and can be useful for determining the application of variable management, irrigation, and fertilization according to vigour [24,25].

The impact of the modernisation of irrigation systems can be evaluated in terms of sustainability in agriculture. This impact is measured in terms of effectiveness. It has allowed a significant increase of the crop yield and water productivity. The farmers are advised to implement these modernisations in order to improve their agricultural water management. In this way it is possible increasing their crop yields and optimizing the storage volumes, particularly for dry years. These evaluations are based on determining the impact of the modernisation of the irrigation module over time, assessing the water productivity before and after the modernization, and evaluating the agricultural production and irrigation volume before and after the modernisation [26].

The concept of food security is also related to sustainability. The quantification of the impact of climate change on food security can be studied by combining climate modelling, crop yield, and demographic evolution under future climatic scenarios. The impact of economical indicators can be analysed with these studies [27].

The management of irrigation based on soil moisture sensors is another application of water sustainability in agriculture [28].

Another aspect of sustainability is the study of nutrient management recommendations. This study can lead to the development of policy and farmer guidelines. An example, can be the intensification of the use of legumes supplied with fertilizers in cropping systems [29].

The influence of urban development on the agricultural water environment is another consideration. By means of stochastic frontier analysis model, robust results can be obtained in the measurement of agricultural water utilization efficiency. Several factors, such as the population urbanization, economic urbanization, balanced urbanization, crop planting ratio, and rice planting ratio, among others, have to be taken into account [30].

Finally, the analysis of the environmental impact of greenhouses in agriculture can be used for sustainable purposes. Cultivation in open fields mainly depends on the location and time of farming, which itself highly depends on the quality and quantity of water for irrigation, weather conditions, and soil characteristics. Water resources are highly dependent on the limited freshwater resources from the groundwater system, or rainwater [31].

Some of the technological advances in water resources management, energy management, agricultural mechanization and construction, extensive crops, viticulture, animal production, and agricultural systems were developed in the "II Symposio Ibérico de Ingeniería Horticola 2020" (http: / / sibeh2020.ipvc.pt, accessed on 17 March 2021), held in Ponte de Lima (Portugal) in March 2020, and organized by Grupo de Ingeniería Hortícola de la Sociedad Española de Ciencias Hortícolas (SECH), Asociación Portuguesa de Horticultura (APH), and Escuela Superior Agraria - Instituto Politécnico de Viana do Castelo (ESAIPVC). Various representatives of the R\&D\&i sector, belonging to various research centres, universities, and companies, participated in this event.

This issue aims to show some of the most innovative scientific contributions presented at the aforementioned symposium, related to precision agriculture and the sustainable use of resources in agriculture.

Some of the studies that have been presented aimed at facilitating decision-making for farmers. Alfosea-Simón et al. have come to the conclusion that the application of 
biostimulants containing amino acids to tomatoes (Solanum lycopersicum L.) can benefit their sustainable cultivation, since they are contributing to the growth of the aerial part, the net assimilation of $\mathrm{CO}_{2}$, and the efficiency of the water usage. Ávila-Dávila et al. estimated the evapotranspiration and the cultivation coefficients of bell pepper using a removable compact weighing lysimeter, comparing the results obtained with the coefficients published by the Food and Agriculture Organization of the United Nations (FAO). These achieved values can be of great help to farmers in determining the water requirements of these types of crops. Barajas et al. evaluated the agronomic, phenological, nutritional, and organoleptic characteristics of pistachios (Pistacia vera L.) from the normalized difference vegetation index (NDVI). This was calculated in the phenological stage of nut filling from Sentinel satellite images. For a certain quality of walnut within a certain orchard, the NDVI is a good index to classify different areas according to their productive capacity. This technology can be useful for applying management, irrigation, and fertilization variables. In the work of Ramos-Teodoro et al., a novel tool is presented to optimally distribute resources in agro-energy centres. This was composed of a set of MATLAB ${ }^{\circledR}$ and Simulink ${ }^{\circledR}$ files that was developed to facilitate decision-making by farmers related to irrigation scheduling, $\mathrm{CO}_{2}$ enrichment, and storage system management. González-Trinidad et al. showed a study carried out in a modernized irrigation module in North-Central Mexico. The results of this study showed a significant increase in crop yields and in the productivity of the water used. Mesfin et al. developed a series of nutrient management recommendations to assist farmers in northern Ethiopia. A decision-making system for the use of legumes was presented. The cultivation of legumes supplied the addition to the soils with $\mathrm{N}$ and $\mathrm{P}$ starter fertilizers. This can represent a sustainable option in cropping systems for the practice of sustainable management of soil fertility.

The proposal by Bañón et al. assesses how variations in the temperature and salinity of the coir affect the output of the Decagon EC5 (voltage) and GS3 (permittivity and bulk EC) sensors. The results showed that the effect of temperature and salinity on the output of the sensors can lead to substantial errors in the humidity estimates.

Defrance et al. present a study that analysed the climatic impact on the production of cereals per capita in West Africa. The study concludes that in 2050 local agricultural production will be below $50 \mathrm{~kg}$ per capita, which can be expected to have an impact on the importation of crops and on regional migration. Zhang et al. show the influence of the characteristics of urbanization development on the efficiency of water use for agriculture. For this purpose, a stochastic frontier analysis model was used. The efficiency of water use for agriculture in the provinces of the Yellow river basin was measured. The study concludes that economic urbanization was significantly negatively related to the efficiency of water use in agriculture. Moreover, the authors note that technology innovation plays a positive role in the use of agricultural water resources. Akrami et al. review emerging trends and practices in analysing greenhouse ventilation requirements to maintain peak agricultural performance.

Finally, two studies related to the recovery of vegetable fibre waste to be used as construction material were presented. In the work of Ferrández-Villena et al., it has been shown that the use of common cane in the manufacture of mixed wood boards can be a good alternative, since its use contributes to the development of more sustainable materials. Lower energy consumption is required for the manufacture of mixed wood boards using common cane than that used in panels of industrial wood, causing considerable industrial and environmental benefit. Ferrández-García et al. state that it is possible to manufacture particle boards composed of residues from the pruning of the Washingtonia filifera palm tree with citric acid as a natural binder that have good thermal and mechanical performance and can be used as interior walls of buildings without the need for coatings.

Acknowledgments: We thank Sonya Song, Assistant Editor of the journal Sustainability for agreeing to host this Special Issue and for her assistance with the editing process. We also wish to give our thanks to the authors of the papers included in this issue and to the reviewers for their invaluable work improving all the papers. 
Conflicts of Interest: The authors declare no conflict of interest.

\section{References}

1. Vaughan, P.J.; Trout, T.J.; Ayars, J.E. A processing method for weighing lysimeter data and comparison to micrometeorological ETo predictions. Agric. Water Manag. 2007, 88, 141-146. [CrossRef]

2. Hoffman, M.; Schwartengräber, R.; Wessolek, G.; Peters, A. Comparison of simple rain gauge measurements with precision lysimeter data. Atmos. Res. 2016, 174-175, 120-123. [CrossRef]

3. Velázquez-Martí, B.; Sajdak, M.; López-Cortés, I. Available residual biomass obtained from pruning Morus alba L. trees cultivated in urban forest. Renew. Energy 2013, 60, 27-33. [CrossRef]

4. Turgut Sahin, H.; Burak Arslan, M. Weathering performance of particleboards manufactured from blends of forest residues with Red pine (Pinus brutia) wood. Maderas Cienc. Tecnol. 2011, 13, 337-346. [CrossRef]

5. Hiziroglu, S.; Holcomb, R. Some of the properties of three-layer particleboard made from eastern red cedar. Build. Environ. 2005, 40, 719-723. [CrossRef]

6. Nasser, R.A. Physical and mechanical properties of three-layer particleboard manufactured from the tree pruning of seven wood species. World Appl. Sci. J. 2012, 19, 741-753.

7. Duarte da Silva, M.J.; Bezerra, B.S.; Gomes Battistelle, R.A.; De Domenico Valareli, I. Prospects for the use of municipal tree pruning wastes in particleboard production. Waste Manag. Res. 2013, 31, 960-965. [CrossRef] [PubMed]

8. Lykidis, C.; Grigoriou, A.; Barboutis, I. Utilisation of wood biomass residues from fruit tree branches, evergreen hardwood shrubs and Greek fir wood as raw materials for particleboard production. Part A. Mechanical properties. Wood Mater. Sci. Eng. 2014, 9, 202-208. [CrossRef]

9. Fiorelli, J.; Galo, R.G.; Junior, S.C.; Belini, U.L.; Lasso, P.R.O.; Savastano, H. Multilayer particleboard produced with agroindustrial waste and Amazonia vegetable fibres. Waste Biomass Valorization 2018, 9, 1151-1161. [CrossRef]

10. Fiorelli, J.; Bueno, S.B.; Cabral, M.R. Assessment of multilayer particleboards produced with green coconut and sugarcane bagasse fibers. Constr. Build. Mater. 2019, 205, 1-9. [CrossRef]

11. Bui, H.; Sebaibi, N.; Boutouil, M.; Levacher, D. Determination and Review of Physical and Mechanical Properties of Raw and Treated Coconut Fibers for Their Recycling in Construction Materials. Fibers 2020, 8, 37. [CrossRef]

12. Batiancela, M.A.; Acda, M.N.; Cabangon, R.J. Particleboard from waste tea leaves and wood particles. J. Compos. Mater. 2014, 48, 911-916. [CrossRef]

13. Sam-Brew, S.; Smith, G.D. Flax and Hemp fiber-reinforced particleboard. Ind. Crops Prod. 2015, 77, 940-948. [CrossRef]

14. Sánchez, M.L.; Morales, L.Y.; Caicedo, J.D. Physical and mechanical properties of agglomerated panels made from bamboo fiber and vegetable resin. Constr. Build. Mater. 2017, 156, 330-339. [CrossRef]

15. Ferrandez-García, M.T.; Ferrandez-Garcia, C.E.; Garcia-Ortuño, T.; Ferrandez-Garcia, A.; Ferrandez-Villena, M. Study of Waste Jute Fibre Panels (Corchorus capsularis L.) Agglomerated with Portland Cement and Starch. Polymers 2020, 12, 599. [CrossRef] [PubMed]

16. Ferrandez-Villena, M.; Ferrandez-Garcia, C.E.; Garcia-Ortuño, T.; Ferrandez-Garcia, A.; Ferrandez-Garcia, M.T. The influence of processing and particle size on binderless particleboards made from Arundo donax L. rhizome. Polymers 2020, 12, 696. [CrossRef]

17. Ferrandez-García, M.T.; Ferrandez-Garcia, A.; Garcia-Ortuño, T.; Ferrandez-Garcia, C.E.; Ferrandez-Villena, M. Assessment of the Physical, Mechanical and Acoustic Properties of Arundo donax L. Biomass in Low Pressure and Temperature Particleboards. Polymers 2020, 12, 1361. [CrossRef]

18. Ferrandez-Villena, M.; Ferrandez-Garcia, C.E.; Garcia-Ortuño, T.; Ferrandez-Garcia, A.; Ferrandez-Garcia, M.T. Analysis of the thermal insulation and fire-resistance capacity of particleboards made from vine (Vitis vinifera L.) prunings. Polymers 2020, 12, 1147. [CrossRef]

19. Ferrández-García, C.E.; Andreu-Rodríguez, J.; Ferrández-García, M.T.; Ferrández-Villena, M.; García-Ortuño, T. Panels made from giant reed bonded with non-modified starches. BioResources 2012, 7, 5904-5916. [CrossRef]

20. Ferrandez-Garcia, M.T.; Ferrandez-Garcia, C.E.; Garcia-Ortuño, T.; Ferrandez-Garcia, A.; Ferrandez-Villena, M. Experimental Evaluation of a New Giant Reed (Arundo donax L.). Composite Using Citric Acid as a Natural Binder. Agronomy $2019,9,882$. [CrossRef]

21. Alfosea-Simon, M.; Simon-Grao, S.; Zavala-Gonzalez, E.A.; Camara-Zapata, J.M.; Simon, I.; Martinez-Nicolas, J.J.; Lidon, V.; Garcia-Sanchez, F. Physiological, Nutritional and Metabolomic Responses of Tomato Plants After the Foliar Application of Amino Acids Aspartic Acid, Glutamic Acid and Alanine. Front. Plant. Sci. 2021, 11, 581234. [CrossRef] [PubMed]

22. Farah, A.; Hassan, H.; Abdelshafy, M.A.; Mohamed, M.A. Optimal scheduling of hybrid multi-carrier system feeding electri$\mathrm{cal} /$ thermal load based on particle swarm algorithm. Sustainability 2020, 12, 4701. [CrossRef]

23. Muñoz, M.; Gil, J.D.; Roca, L.; Rodríguez, F.; Berenguel, M. An IoT architecture for water resource management in agroindustrial environments: A case study in Almería (Spain). Sensors 2020, 20, 596. [CrossRef] [PubMed]

24. Vélez, S.; Barajas, E.; Rubio, J.A.; Vacas, R.; Poblete-Echeverría, C. Effect of missing vines on total leaf area determined by NDVI calculated from Sentinel satellite data: Progressive vine removal experiments. Appl. Sci. 2020, 10, 3612. [CrossRef]

25. Mercier, A.; Betbeder, J.; Baudry, J.; Le Roux, V.; Spicher, F.; Lacoux, J.; Roger, D.; Hubert-Moy, L. Evaluation of Sentinel-1 \& 2 time series for predicting wheat and rapeseed phenological stages. ISPRS J. Photogramm. Remote Sens. 2020, 163, $231-256$. 
26. Borrego-Marín, M.M.; Berbel, J. Cost-benefit analysis of irrigation modernization in Guadalquivir River Basin. Agric. Water Manag. 2019, 212, 416-423. [CrossRef]

27. Sultan, B.; Defrance, D.; Iizumi, T. Evidence of crop production losses in West Africa due to historical global warming in two crop models. Sci. Rep. 2019, 9, 12834. [CrossRef] [PubMed]

28. Incrocci, L.; Marzialetti, P.; Incrocci, G.; Di Vita, A.; Balendonck, J.; Bibbiani, C.; Spagnol, S.; Pardossi, A. Sensor-based management of container nursery crops irrigated with fresh or saline water. Agric. Water Manag. 2019, 213, 49-61. [CrossRef]

29. Mesfin, S.; Taye, G.; Hailemariam, M. Effects of integrated soil and water conservation measures on soil aggregate stability, soil organic matter and soil organic carbon stock of smallholder farmlands in semi-arid Northern Ethiopia. Carbon Manag. 2018, 9, 155-164. [CrossRef]

30. Liu, Y.Y.; Mao, D.H. Integrated Assessment of Water Quality Characteristics and Ecological Compensation in the Xiangjiang River, South-central China. Ecol. Indic. 2020, 110, 105922. [CrossRef]

31. Zhang, G.; Ding, X.; Li, T.; Pu, W.; Lou, W.; Hou, J. Dynamic energy balance model of a glass greenhouse: An experimental validation and solar energy analysis. Energy 2020, 198, 117281. [CrossRef] 